Research.

\title{
Analysis of performance appraisal system with 360 degree feedback method in PT. PERTAMINA RU IV (PERSERO) Cilacap
}

\author{
Dina Prasetyaningrum ${ }^{1 *}$, Yudi Agus Setiawan ${ }^{2}$ \\ Department of Management, Nahdlatul Ulama Al Ghazali University, Cilacap, Indonesia \\ ${ }^{1)^{*}}$ dinaprasetyaningrum.dp@gmail.com; ${ }^{2)}$ namakuyudiagus@gmail.com \\ * Corresponding author
}

Received: November 5, 2020; Accepted: November 16, 2020; Published: December 31, 2020

To cite this article: Prasetyaningrum, D; Setiawan, Y.A. (2020). Analysis of performance appraisal system with 360 degree feedback method in PT. Pertamina RU IV (Persero) Cilacap. The Management Journal of BINANIAGA, 5 (2), 105-114. doi: $10.33062 / \mathrm{mj}$ b.v5i2.399

\begin{abstract}
The 360 degree feedback method is one of the performance appraisal methods which implementation takes an assessment of the parties around the employee being assessed. The 360 degree feedback method performance appraisal system conducted at PT. Pertamina RU IV (Persero) Cilacap aims to determine the implementation of the performance appraisal system using the 360 degree feedback method, determine employee performance with what variables are used in performance appraisal, and obtain performance optimization. The research method used in this research uses qualitative methods with a quantitative approach. The 360 degree feedback method is used to find data from respondents, namely from superiors, colleagues, themselves and subordinates. Based on the research that had been done, it had succeeded in determining the best workers from each discipline and position based on the calculation of variables and indicators used. The 360 degree feedback performance assessment can help the company appropriately to provide rewards for workers with the highest percentage and provide punishment for workers with lowest percentage. The calculation of these variables and indicators helps the company to find the right solution in an effort to optimize the performance of its employees.
\end{abstract}

Keywords: performance, performance appraisal, 360 degree feedback method

\section{INTRODUCTION}

Human resources are very important for the company is the workforce. Workforce training and development need to be applied by company owners so that their workforce becomes productive human resources that must be developed and prepared to face all conditions experienced. The process of improving HR development needs to be carried out by an employee performance appraisal aimed at developing a sense of commitment to the organization, personality, attitudes or behavior, and employee mindset.

Performance appraisal is an important value in the measurement system for the contributions of individuals to performance in the organization because the completion of workforce tasks which are their responsibility involves determining the level of individual contributions to the performance carried out (Handoko, 2011).

Company managers are tasked with evaluating and assessing employee performance including assessing loyalty, honesty, leadership, cooperation, loyalty, dedication, and employee participation and determining further policies (Hasibuan, 2009). One of the most important and difficult components to achieve an effective employee performance appraisal is that the employee performance appraisal must be free from bias (Ahmad \& Bujang, 2013). A more effective and valid employee performance appraisal is an employee performance appraisal that involves more than one assessor (Kipcumbha, 2014). 
Maximizing the performance of an HR (Human Resources) in a company requires the ability to apply skills or competencies. Competency is divided into two, namely hard competency and soft competency. Hard competency emphasizes the completion of work based on technical work involving knowledge and skills. In its implementation, hard competency applies formal knowledge obtained through formal education. Soft competency is the technical ability to carry out work effectively which is related to the ability to manage work processes through peer-topeer relationships that involve communication, leadership, and other interaction skills (Sutrisno, 2009).

The 360 degree feedback method is concluded as a performance appraisal method carried out by many parties so that the results obtained are expected to be more honest, fair and on target. By using the performance method an employee is assessed based on feedback from everyone with whom he has a working relationship, namely superiors, colleagues, partners, subordinates and customers. This method collects input from various sources in the work environment of employees (Adryanto, 2011).

PT. Pertamina as a state-owned company that has been established since 1974 is engaged in the energy sector including oil, gas, new and renewable energy, pays close attention to current industrial developments. PT. Pertamina must also be able to manage and increase employee loyalty and productivity to achieve organizational goals in accordance with the company's vision and mission. Based on the results of observations, the performance appraisal of the 360 degree feedback method with the hard competency component has not been used in the company PT. Pertamina RU IV (Persero) Cilacap.

Based on the background described above, the authors conducted a study entitled "Analysis of Performance Appraisal Systems with the 360 Degree Feedback Method at PT. Pertamina RU IV (Persero) Cilacap ".

The 360 degree feedback method performance appraisal system conducted at PT. Pertamina RU IV (Persero) Cilacap aims to determine the implementation of the performance appraisal system with the 360 degree feedback method, find out the performance appraisal with what variables are used in the 360 degree feedback method, and obtain performance optimization.

\section{LITERATURE REVIEW}

Basically, human resources are very important assets for the company and are crucial in achieving company goals (Burtonshaw-Gunn \& Salameh, 2009). Therefore, every company or organization that wants to improve the performance of its employees focuses on 4 (four) things, each of which has a relationship, namely competencies, attitudes or behavior, skills, and knowledge. .

The 360 degree feedback method is an evaluation method that combines feedback from the employees themselves, their colleagues, direct superiors, subordinates and customers. The results obtained and are confidential are then tabulated and distributed to the employees being assessed by a manager (Linman, 2015). In this method, the assessment is carried out by several parties, namely colleagues, direct supervisors / supervisors (supervisors / superior), subordinates, customers and suppliers if necessary.

Karmawijaya as quoted by Lharansia (2009) explains that the direction and purpose of implementing the 360 degree feedback method in an organization or company is for individual development, team development, and human resource development or human resource management audits.

According to Lepsinger, et.al (2015) they are stages of implementation in the performance appraisal with the 360 degree feedback assessment system which is developing a questionnaire. The questionnaire used in the 360 degree feedback performance appraisal system contains questions using a 1-5 scale system, monitoring feedback from the 
questionnaire, by distributing questionnaires with instructions that prevent misunderstandings, and data analysis that will include an assessment of average performance.

Research conducted by Efranto, et.al (2015) concluded that based on the 360 degree feedback method, some employees showed an increase in the results of the assessment when compared to the results of the current assessment, and some others showed a decrease in the results of the assessment compared to the results of the current assessment.

Research from Rahmayanti shows the results of the implementation and use of performance appraisals with the 360 degree method at PT Arga Bangun Bangsa can provide information about the optimization of the 360 degree method's performance appraisal, so that the benefits, directions, and objectives are summarized (Rahmayanti, 2018).

Based on research conducted by Siregar (2018), conclusions can be drawn to create an employee performance appraisal model with four assessors, namely direct supervisors, peers, oneself, and subordinates, the variables used are integrity, quality orientation, customer orientation, collaboration, communication, skills, loyalty, planning and organizing, and coaching. The results of the performance appraisal will produce performance grade information (I, II, III, IV, and V) that describes the work performance during the 1 year working period.

\section{RESEARCH METHODOLOGY}

The research method used qualitative methods with a quantitative approach. The population used is the employees of PT. Pertamina RU IV (Persero) Cilacap. Samples were taken using a simple random sampling technique in the MA5 Maintenance Area which consisted of electrical discipline, instrument discipline, rotating discipline and stationary discipline. The research location is at PT. Pertamina RU IV (Persero) Cilacap, JI. MT Haryono No. 77 Lomanis Cilacap.

Data collection methods are by observation, interviews, questionnaires, documentation, data archives and various reference sources. The data collected for this study included data on the number of MA5 Maintenance Area employees consisting of the MA5 section head (1 person), supervisor (2 people), electrical discipline (5 people), instrument discipline (6 people), rotating discipline (4 people), and stationary discipline. (6 people); company organizational structure data; and performance appraisal weighting data to design employee performance appraisal forms using the 360 degree feedback method along with its variables and indicators.

The work appraisal process using the 360 degree feedback method includes input, process and output. Research on 360 degree feedback performance appraisal with hard and soft competency components which will be conducted at PT. Pertamina RU IV (Persero) Cilacap uses 4 (four) variables. These variables are:

1. Competencies. Performance appraisal competency variables are measured by indicators including taskskills (able to perform tasks per task), task management skills (able to manage several different tasks in a job), contingency management skills (responsiveness to abnormalities and damage to work routines), job roles environment skills (able to face responsibilities and expectations) from the work environment), and transferskill (being able to transfer the competencies that are owned in each different situation, a new situation or a new workplace) (Moeheriono, 2010).

2. Attitude or behavior. The attitude variable or performance appraisal behavior is measured by indicators including cognitive (trust), affective (emotion), conative (behavior) ((Secord \& Backman, 2015)

3. Skills. Variable skills are measured by indicators including basic literacy skills, technical skills, interpersonal skills, and problem solving. According to Robbins (2008), basic literacy skills are definite and must-have skills of a person; technical skill (technical expertise) is someone's expertise in developing their own techniques; interpersonalskill (interpersonal

Dina Prasetyaningrum, Yudi Agus Setiawan. Analysis of performance appraisal system with 360 degree feedback method in PT. Pertamina RU IV (Persero) Cilacap 
skills) is the ability to effectively interact with other people and with colleagues; problemsolving (solving problems) is a process activity to sharpen logic, argue and solve problems.

4. Knowledge. Knowledge variables are measured by indicators including understanding the scope of tasks / jobs, understanding the procedures for carrying out tasks / jobs, understanding how to carry out tasks / jobs, understanding the challenges in carrying out tasks / jobs (Robbins \& Timothy, 2008).

\section{RESULTS AND DISCUSSION}

\section{Analysis of Performance Appraisal System with 360 Degree Feedback Method at PT. Pertamina RU IV (Persero) Cilacap}

The vision of PT. Pertamina RU IV (Persero) Cilacap, namely "Being a Competitive Oil Refinery in the World", and the mission of PT. Pertamina RU IV (Persero) Cilacap, namely "Processing Petroleum into Petroleum, Non-Fuel, and Petrochemical Products to Provide Added Value for the Company", with the aim of "Satisfying Stakeholders through Improving Company Performance in a Professional, International Standard, and Environmentally Friendly manner."

Research on performance appraisal using 360 degree feedback method conducted at PT. Pertamina RU IV (Persero) Cilacap uses 4 (four) variables including the hard competency and soft competency components that have been agreed by the Section Head of Human Capital and the Manager of Human Capital RU IV in the Maintenance Area (MA5) RU IV. These variables are:

1. Competencies Indicators used in the performance appraisal of the 360 degree feedback method in the Maintenance Area (MA5) RU IV section are task skills, task management skills, contingency management skills, job role environmentskills, and transferskills.

2. Attitude or behavior Indicators used in the performance appraisal of the 360 degree feedback method in the Maintenance Area (MA5) RU IV are cognitive, affective, and conative.

3. Skills Indicators used in the performance appraisal of the 360 degree feedback method in the Maintenance Area (MA5) RU IV are basic literacy skills, technical skills, interpersonal skills, and problem solving.

4. Knowledge Indicators used in the performance appraisal of the 360 degree feedback method in the Maintenance Area (MA5) RU IV, namely understanding the scope of tasks / jobs, understanding the procedures for carrying out tasks / jobs, understanding how to carry out tasks / jobs, and understanding of the challenges in carrying out tasks / work

360 degree feedback method performance appraisal at PT. Pertamina RU IV (Persero) Cilacap, the appraiser involved 4 (four) parties, namely the section head, supervisor, coworkers, and subordinates. Supervisors are evaluated by the section head, co-workers, subordinates, and themselves. Workers in electrical discipline, instrument discipline, rotating discipline and stationary discipline are evaluated by their direct supervisor, co-workers, and themselves. The 360 degree feedback method of workers will self-assess, and provide a lot of information covering a number of aspects that are not aware of both workers and superiors. Based on the results of the interview, the performance appraisal using the 360 degree feedback method shows that it is a fairer, more accurate, and effective method so that it can achieve company goals in accordance with the company's vision and mission to improve HR development for the company, including:

1. Operate a safe, reliable, efficient and environmentally friendly refinery.

2. Generate high profits.

Dina Prasetyaningrum, Yudi Agus Setiawan. Analysis of performance appraisal system with 360 degree feedback method in PT. Pertamina RU IV (Persero) Cilacap 
3. Creating a work culture that is oriented towards superior performance which refers to the 6C cultural values (clean, confident, customer focus, competitive, capable and commercial).

4. Creating leadership patterns to form visionary, professional, business-oriented leaders and become role models.

5. Establishing a dynamic organization, an effective Manpower System (STK), Pertamina Production System (PPS), Integrated Management System (SMT) and accurate information.

6. Creating a business environment that is transparent, communicative, anticipatory and conducive and provides positive values for stakeholders.

\section{Employee Performance Appraisal with Variables Used in the 360 Degree Feedback Method}

In the process of filling out the assessment form, each variable will be accompanied by an indicator described quantitatively with a numeric parameter. Each point of the performance appraisal indicator is given a value of $1-5$, with a value of $5=$ Excellent, $4=$ Good, $3=$ Fair, $2=$ Poor, 1 = Very poor. The data that has been obtained from the 360 degree feedback questionnaire are then processed with the help of MS. Excel to make it easier to work with. The process of calculating the performance appraisal is (total value of superiors $x$ weight of superior values) + (total value of coworkers $x$ weight of coworkers' value) + (total value of self $x$ weight of own value) + (total value of subordinates $x$ weight of subordinate value). Data from the feedback questionnaire given by superiors, colleagues, subordinates, and themselves for each indicator is multiplied by the weight (\%) of each indicator.

Performance appraisal weight using the 360 degree feedback method at PT. Pertamina RU IV (Persero) Cilacap in the Maintenance Area (MA5) is as follows:

1. The weight of the Appraiser Type, based on the results of discussions with Top Management Human CapitalRU IV in the following table:

Table 1: Assessors' Weight

\begin{tabular}{cccc}
\hline No. & Assessor & Weight (\%) & Weight (\%) \\
\hline 1. & Own-self & 10 & 10 \\
\hline 2. & Superior & 55 & 55 \\
\hline 3. & Co-worker & 20 & 35 \\
\hline 4. & Sub-ordinate & 15 & - \\
\hline & Total & 100 & 100 \\
\hline
\end{tabular}

2. Weighted Value Per Variable and Per Performance Appraisal Indicator, based on the results of discussions with Top Management Human Capital RU IV can be seen in the following table:

Table 2: Weighting of Value per Variable and Per Performance Assessment Indicator

\begin{tabular}{|c|c|c|c|}
\hline No. & Variables & Indicators & Weight (\%) \\
\hline & Competency & task skills & 6 \\
\hline & & task management skills & 6 \\
\hline & & contingency management skills & 6 \\
\hline & & job role environment skills & 7 \\
\hline & & transfer skill & 7 \\
\hline & & Sub-total & 32 \\
\hline & Attitude Or Behaviour & cognitive (trust) & 6 \\
\hline & & afective (emotion) & 6 \\
\hline
\end{tabular}

Dina Prasetyaningrum, Yudi Agus Setiawan. Analysis of performance appraisal system with 360 degree feedback method in PT. Pertamina RU IV (Persero) Cilacap 
The Management Journal of BINANIAGA Vol. 05, No. 02, December 2020

p-ISSN: 2527 - 4317, e-ISSN: $2580-149 x$

$6^{\text {th }}$ Accreditation Rating: April 04, $2019-$ April 03, 2024

\begin{tabular}{|c|c|c|c|}
\hline No. & Variables & Indicators & Weight (\%) \\
\hline & & conative (behaviour) & 7 \\
\hline & & Sub Total & 19 \\
\hline \multirow{5}{*}{\multicolumn{2}{|c|}{ 3. $\quad$ Skills }} & basic literacy skill & 6 \\
\hline & & technical skill & 6 \\
\hline & & interpersonal skill & 6 \\
\hline & & problem solving & 7 \\
\hline & & Sub otal & 25 \\
\hline \multirow{6}{*}{\multicolumn{2}{|c|}{ 4. Knowledge }} & scope of tasks / jobs & 6 \\
\hline & & procedures for implementing tasks / jobs & 6 \\
\hline & & how to carry out tasks / jobs & 6 \\
\hline & & challenges in carrying out tasks & 6 \\
\hline & & Sub-total & 24 \\
\hline & & Total & 100 \\
\hline
\end{tabular}

The results of processing and analyzing the performance appraisal questionnaire using the 360 degree feedback method in the Maintenance Area (MA5) RU IV, the percentage results are obtained in the following table:

Table 3: Recapitulation of Overall Ratings per Variable and Indicator in Percentage (\%) 360 Degree Feedback Method

\begin{tabular}{|c|c|c|c|c|c|c|c|c|c|}
\hline No. & Variables & Indicators & $\begin{array}{c}\text { Electricty } \\
\text { Disciplines }\end{array}$ & $\begin{array}{l}\text { Instrument } \\
\text { Disciplines }\end{array}$ & $\begin{array}{c}\text { Rotating } \\
\text { Disciplines }\end{array}$ & $\begin{array}{c}\text { Stationary } \\
\text { Disciplines }\end{array}$ & $\begin{array}{c}\text { Supervisor } 1 \\
\text { MA5 }\end{array}$ & $\begin{array}{c}\text { Supervisor } 2 \\
\text { MA5 }\end{array}$ & $\begin{array}{l}\text { Average of } \\
\text { Variable } \\
\text { and } \\
\text { Indicator } \\
\text { Rating (\%) }\end{array}$ \\
\hline \multirow[t]{6}{*}{1.} & \multirow[t]{6}{*}{ Competency } & task skills & 93,80 & 94,00 & 95,00 & 92,46 & 86,55 & 84,00 & 90,97 \\
\hline & & $\begin{array}{l}\text { task } \\
\text { management } \\
\text { skills }\end{array}$ & 92,80 & 94,00 & 96,00 & 92,79 & 98,36 & 97,90 & 95,31 \\
\hline & & $\begin{array}{l}\text { contingency } \\
\text { management } \\
\text { skills }\end{array}$ & 91,10 & 92,60 & 85,00 & 80,79 & 95,82 & 95,90 & 90,20 \\
\hline & & $\begin{array}{l}\text { job role } \\
\text { environment } \\
\text { skills }\end{array}$ & 83,07 & 85,56 & 82,25 & 81,90 & 81,97 & 82,03 & 82,80 \\
\hline & & transfer skill & 80,00 & 83,33 & 80,50 & 80,00 & 81,09 & 80,30 & 80,87 \\
\hline & & $\begin{array}{l}\text { Sub Score of } \\
\text { Compentency }\end{array}$ & 88,15 & 89,90 & 87,75 & 85,59 & 88,76 & 88,03 & 88,03 \\
\hline \multirow[t]{4}{*}{2.} & \multirow[t]{4}{*}{$\begin{array}{l}\text { Attitude or } \\
\text { Behaviour }\end{array}$} & $\begin{array}{l}\text { Cognitive } \\
\text { (trust) }\end{array}$ & 87,50 & 90,00 & 89,75 & 89,83 & 84,09 & 82,05 & 87,20 \\
\hline & & $\begin{array}{l}\text { affective } \\
\text { (emotion) }\end{array}$ & 90,40 & 90,88 & 83,45 & 84,58 & 86,43 & 83,65 & 86,56 \\
\hline & & $\begin{array}{l}\text { conative } \\
\text { (behaviour) }\end{array}$ & 81,27 & 85,89 & 72,67 & 72,57 & 80,27 & 76,57 & 78,21 \\
\hline & & $\begin{array}{c}\text { Sub Score of } \\
\text { Attitude } \\
\text { Behavior }\end{array}$ & 86,39 & 88,92 & 81,95 & 82,33 & 83,60 & 80,76 & 83,99 \\
\hline \multirow[t]{5}{*}{3.} & \multirow[t]{5}{*}{ Skills } & $\begin{array}{l}\text { basic literacy } \\
\text { skill }\end{array}$ & 81,27 & 84,89 & 84,42 & 85,46 & 81,82 & 79,43 & 82,88 \\
\hline & & technical skill & 72,20 & 70,50 & 69,00 & 69,33 & 74,55 & 76,30 & 71,98 \\
\hline & & $\begin{array}{l}\text { interpersonal } \\
\text { skill }\end{array}$ & 76,30 & 78,25 & 73,50 & 70,63 & 76,95 & 76,90 & 75,42 \\
\hline & & $\begin{array}{l}\text { problem } \\
\text { solving }\end{array}$ & 70,40 & 67,83 & 69,00 & 70,46 & 85,27 & 87,00 & 74,99 \\
\hline & & $\begin{array}{c}\text { Sub Score of } \\
\text { Skills }\end{array}$ & 75,04 & 75,37 & 73,98 & 73,97 & 79,65 & 79,91 & 76,32 \\
\hline 4. & Knowledge & $\begin{array}{l}\text { scope of tasks } \\
\text { / jobs }\end{array}$ & 83,60 & 81,83 & 93,75 & 91,00 & 94,36 & 91,00 & 89,26 \\
\hline
\end{tabular}

Dina Prasetyaningrum, Yudi Agus Setiawan. Analysis of performance appraisal system with 360 degree feedback method in PT. Pertamina RU IV (Persero) Cilacap

Page : 110 


\begin{tabular}{|c|c|c|c|c|c|c|c|c|c|}
\hline No. & Variables & Indicators & $\begin{array}{c}\text { Electricty } \\
\text { Disciplines }\end{array}$ & $\begin{array}{l}\text { Instrument } \\
\text { Disciplines }\end{array}$ & $\begin{array}{c}\text { Rotating } \\
\text { Disciplines }\end{array}$ & $\begin{array}{c}\text { Stationary } \\
\text { Disciplines }\end{array}$ & $\begin{array}{c}\text { Supervisor } 1 \\
\text { MA5 }\end{array}$ & $\begin{array}{c}\text { Supervisor } 2 \\
\text { MA5 }\end{array}$ & $\begin{array}{l}\text { Average of } \\
\text { Variable } \\
\text { and } \\
\text { Indicator } \\
\text { Rating (\%) }\end{array}$ \\
\hline \multirow[t]{4}{*}{4.} & Knowledge & $\begin{array}{l}\text { procedures } \\
\text { for } \\
\text { implementing } \\
\text { tasks / jobs }\end{array}$ & 78,60 & 81,83 & 69,50 & 70,46 & 78,27 & 80,30 & 76,49 \\
\hline & & $\begin{array}{l}\text { how to carry } \\
\text { out tasks / } \\
\text { jobs }\end{array}$ & 80,40 & 83,00 & 93,75 & 92,46 & 82,82 & 80,30 & 85,45 \\
\hline & & $\begin{array}{l}\text { challenges in } \\
\text { carrying out } \\
\text { tasks }\end{array}$ & 80,00 & 84,50 & 82,75 & 80,33 & 81,09 & 80,30 & 81,50 \\
\hline & & $\begin{array}{c}\text { Sub Score of } \\
\text { Knowledge }\end{array}$ & 80,65 & 82,79 & 84,94 & 83,56 & 84,14 & 82,98 & 83,18 \\
\hline
\end{tabular}

Source: Processed Data

Table 4: Overall Recapitulation of Performance Appraisal 360 Degree Feedback Method with Weighted Assessors, Variables and Indicators

\begin{tabular}{|c|c|c|c|c|c|c|}
\hline \multirow{2}{*}{\multicolumn{2}{|c|}{ Position }} & \multicolumn{4}{|c|}{ Assessment Variables (\%) } & \multirow{2}{*}{$\begin{array}{c}\text { Total Variables Per } \\
\text { Position (\%) }\end{array}$} \\
\hline & & Competency & $\begin{array}{l}\text { Attitude or } \\
\text { Behaviour }\end{array}$ & Skills & Knowledge & \\
\hline & Supervisor 1 MA5 & 28,26 & 15,85 & 19,97 & 20,19 & 84,27 \\
\hline & Supervisor 2 MA5 & 28,03 & 15,30 & 20,05 & 19,91 & 83,30 \\
\hline 3. & Electricty Disciplines Staff & 28,08 & 16,36 & 18,71 & 19,36 & 82,51 \\
\hline & $\begin{array}{l}\text { Instrument Disciplines } \\
\text { Staff }\end{array}$ & 28,66 & 16,86 & 18,77 & 19,87 & 84,16 \\
\hline & Rotating Disciplines Staff & 27,95 & 15,48 & 18,45 & 20,39 & 82,26 \\
\hline & $\begin{array}{l}\text { Stationary Disciplines } \\
\text { Staff }\end{array}$ & 27,30 & 15,54 & 18,46 & 20,06 & 81,35 \\
\hline & $\begin{array}{l}\text { MA5 Performance } \\
\text { ssessment Results }\end{array}$ & 28,05 & 15,90 & 19,07 & 19,96 & 82,98 \\
\hline
\end{tabular}

Source: Processed Data

Based on the results of data processing in table 3, the evaluation of the performance of the Maintenance Area (MA5) RU IV as a whole obtained the highest variable assessment with a value of $88.03 \%$ on the competency variable and the lowest variable assessment with a value of $76.32 \%$ in the skill variable. As for the indicator assessment with the highest score of $95.31 \%$ on task management skills and the lowest score for indicator assessment of $71.98 \%$ on technical skills. The variable component of performance assessment which includes hard competency and soft competency is a very important thing that human resources must have for the development of the company according to the vision and mission. The variables and indicators used in the performance appraisal of the 360 degree feedback method at PT. Pertamina RU IV (Persero) Cilacap really helps management to analyze the things that become obstacles and shortcomings for the company in achieving its goals and things that must be maintained and improved for the progress of the company. Efforts to improve skills can be done by conducting seminars and training so that will improve and develop work skills in a professional manner. In addition, employee rotation can also be done to reduce the stress level of workers, increase and develop skill levels so that workers can do various jobs with the skills acquired during worker rotation.

Based on the results of data processing in table 4, the overall performance assessment of the Maintenance Area (MA5) RU IV workers was $82.98 \%$ in the very good category with the highest order in supervisor 1 MA5 $84.27 \%$ who led the electrical discipline staff and instrument disciplinary staff. The lowest was on stationary disciplinary staff with a value of $81.35 \%$. The achievement of the highest competency variable value was for instrument disciplinary staff with a value of $28.66 \%$ and the lowest was for stationary disciplinary staff with a value of $27.30 \%$. The attainment of the highest value of attitude or behavior variables was for instrument disciplinary staff with a value of $16.86 \%$ and the lowest was for supervisors 2 MA5 who led

Dina Prasetyaningrum, Yudi Agus Setiawan. Analysis of performance appraisal system with 360 degree feedback method in PT. Pertamina RU IV (Persero) Cilacap 
rotating disciplinary staff and stationary disciplinary staff with a value of $15.30 \%$. The achievement of the highest skill variable value was on the supervisor 2 MA5 with a value of $20.05 \%$ and the lowest was the rotating discipline staff with a value of $18.45 \%$. The achievement of the highest knowledge variable value was for rotating disciplinary staff with a value of $20.39 \%$ and the lowest was for the electrical disciplinary staff with a value of $19.36 \%$. The results of this assessment indicate that overall the Maintenance Area (MA5) workers already have very good performance and good work results. The existence of rewards given to the best workers is one proof that management is very concerned about and focused on improving employee performance as gratitude and appreciation for their contribution to the progress of the company, as well as the existence of punishment to motivate employees to work optimally so that worker performance is more effective in the company.

\section{Optimizing Employee Performance of PT. Pertamina RU IV (Persero) Cilacap}

The results of the calculation of the percentage of worker's performance appraisal using the 360 degree feedback method at PT. Pertamina RU IV (Persero) Cilacap in the Maintenance Area (MA5) RU IV, in detail, the variables and indicators used have provided an overview and insights regarding the amount of value in percentage measured in each discipline and position. The results of this percentage can be a measuring tool in an effort to optimize performance appraisal using the 360 degree feedback method at PT. Pertamina RU IV (Persero) Cilacap.

Based on the results of the percentage of variables and indicators used in the performance appraisal of the 360 degree feedback method in the Maintenance Area (MA5) RU IV, it illustrates that the 360 degree feedback method performance appraisal can provide performance optimization for any discipline which includes staff, supervisors and all workers to further improve performance and generate profits. which is high for the company. The following is the optimization of performance in managing human resources in accordance with company objectives, including:

1. Human resource management includes the planning, fulfillment of needs, selection, placement, development, transfer and dismissal of workers.

2. Benefits of HR management so that the company always has superior human resources and can be directed and empowered to achieve company goals.

3. Organizational analysis and analysis of the availability of workers are carried out in accordance with business strategies and company developments in workforce planning.

4. Manpower procurement is carried out based on company requirements in accordance with the criteria and competency requirements of the position required by the company.

5. A transparent and objective selection process needs to be done in recruiting workers.

6. The company needs to carry out a process of placing new workers recruited by the company in accordance with the needs and interests of the company by prioritizing the principle of justice for existing workers.

7. Employee development to increase workers' knowledge and competence through education and training as well as special assignments to achieve goals, improve company performance, and fulfill competency and at the same time develop employee career.

\section{CONCLUSIONS AND SUGGESTIONS} be drawn:

Based on the research that had been done, the following conclusions and suggestions can

1. Performance appraisal of the 360 degree feedback method with four assessors, namely direct supervisors, colleagues, themselves, and subordinates (for workers who have subordinates) with the variables used are competence, attitude or behavior, skills, and knowledge.

2. Performance appraisal of the Maintenance Area (MA5) RU IV employees to produce information as a whole obtained a value of $82.98 \%$ with the highest variable in the competency variable obtained a value of $88.03 \%$.

Dina Prasetyaningrum, Yudi Agus Setiawan. Analysis of performance appraisal system with 360 degree feedback method in PT. Pertamina RU IV (Persero) Cilacap

Page : 112 
3. Based on interviews with Top Management Human Capital RU IV, the variable components of hard competency and soft competency with 360 degree feedback can be implemented by the company to optimize performance in human resource management in accordance with company goals.

4. Performance appraisal using the 360 degree feedback method will provide feedback for the assessed party so that they can provide self-evaluation for career development.

\section{REFERENCES}

Adryanto, M. (2011). Mengenali Metode Penilaian 360 Accesed August 10, 2019, from http://michaeladryanto.wordpress.com:

http://michaeladryanto.wordpress.com/2011/11/09/mengenali-metode-penilaian-360 derajat/

Ahmad, R., \& Bujang, S. (2013). Issues and Challenges in the practice of Performance Appraisal Activities in the 21st Century. International Journal of Education and research,1(4) , 1-8. https://www.ijern.com/images/April-2013/45.pdf

Burtonshaw-Gunn, S. A., \& Salameh, M. G. (2009). Essential tools for organizational performance: tools, models andapproaches for managers and consultants. John Wiley \& Sons, Ltd.

Efranto, R. Y., Riawati, L., \& Dinaputri, R. S. (2015). Perancangan Penilaian Kinerja Karyawan pada Perusahaan Furniture dengan Metode 360 Degrees Feedback. Journal of Enginering and Management in Industrial System , 3 (2), 111-119. https://doi.org/10.21776/ub.jemis.2015.003.02.8

Handoko, T. H. (2011). Manajemen Personalia dan Sumber Daya Manusia. BPFE Yogyakarta.

Hasibuan, M. S. (2009). Manajemen Dasar Pengertian dan Masalah. Jakarta: Bumi Aksara.

Kipcumbha, T. (2014). Effectiveness of the 360 Degree Appraisal Tool in Human Resource Practice in Kenya. HeraldJournal of Marketing and Business Management , 3(1),10-21.

Lepsinger, R., Aanntoinette, D., \& Lucia. (2015). The Art and Science 360 Degree Feedback. San fransisco: Pfifer.

Lharansia, R. (2009). Faktor-faktor Penentu Efektivitas Sistem Penilaian Kompetensi 360 Derajat pada PT. X Bogor. Skripsi, Institut Pertanian Bogor.

Linman, T. (2015). 360-degree Feedback: Weighing the Pros and Cons. journal, San Diego State University .

Moeheriono. (2010). Pengukuran Kinerja Berbasis Kompetensi. Penerbit Ghalia Indonesia.

Rahmayanti. (2018). Analisis Sistem Penilaian Kinerja Karyawan dengan Menggunakan Metode 360 Derajat (Studi Kasus pada PT. Arga Bangun Bangsa). Jurnal Sekretari Universitas Pamulang , 5 (2), 1-16. http://dx.doi.org/10.32493/skr.v5i2.2035.

Robbins, S. P., \& Timothy, A. J. (2008). Perilaku Organisasi. Salemba Empat.

Secord, P., \& Backman, C. (2015). Social Psychology (2nd Edition ed.). New York: McGraw-Hill Book Company.

Dina Prasetyaningrum, Yudi Agus Setiawan. Analysis of performance appraisal system with 360 degree feedback method in PT. Pertamina RU IV (Persero) Cilacap 
The Management Journal of BINANIAGA Vol. 05, No. 02, December 2020

p-ISSN: 2527 - 4317, e-ISSN: $2580-149 x$

$6^{\text {th }}$ Accreditation Rating: April 04, 2019 - April 03, 2024

Siregar, M. J. (2018). Rancang Model Penilaian Kinerja Karyawan dengan Metode 360 Degree di Departemen Warehouse. Jurnal Profisiensi , 6 (1), 33-40.

https://www.journal.unrika.ac.id/index.php/jurnalprofisiensi/article/view/1455

Sutrisno, E. (2009). Manajemen Sumber Daya Manusia. Jakarta: Kencana.

Dina Prasetyaningrum, Yudi Agus Setiawan. Analysis of performance appraisal system with 360 degree feedback method in PT. Pertamina RU IV (Persero) Cilacap 